\title{
A possible general mechanism of the signal transfer switching on the $\alpha / \beta$-interferons expression. 1. The local cell membrane deformation as the first induction stage
}

\author{
Alexander V. Karpov \\ Danylo Zabolotny lnstitute of Microbiology and Virology, National Academy of Sciences of Ukraine \\ 154 Zabolotny sir., Kyiv, 252143
}

\begin{abstract}
A hypothetic mechanism of the external effect of viruses, synthetic polyaniones, double stranded RNAs, and synthetic double-stranded polyribonucleotides upon a cell is explained. This effect is known to be followed by the $\alpha / \beta-I F N$ induction. Double-stranded RNAs and polynucleotides inducing such precis ate thought to change their conformation in an outer ionic perimembrane layer of cells and to imluat in specific local deformation of cell membranes giving a signal for the $\alpha / \beta-I F N$ inducticin. In the cist:

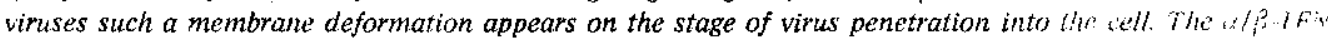
inducers of intercalating nature are proposed to cause the interferonogenesis in vivo forming comple.s. with exogenic RNA molecules and stabilizing their double-stranded sites with a partul complementurity:
\end{abstract}

The synthesis of interfercins (IFNs) as well as of many olber cytokines is regulated by induction, $i$. e. by the extracellular IFN renes activation [1]. The data concerning the $\alpha / \beta-$ IF Ns confirm their activation both by vinuses and by a lot of different high and low molecular weight compounds. The IFN-inductive effect of natural double-stranded RNAs (dsR NAs) and of :aynthetic polynucleotides has been studied in detail [1--4]. However, the earliest IFN-inducing stage as well as some intial inducer-cell interactions and the rols: of such interactions for the signal transfer followed by the gene expression have not been yet completely investigated.

Almost all the hypotheses describing the IFN induction mechanism by dsRNAs and synthetic polvnucleotides are based on the presumption the asR NAdirecied induction process to be completely due to sone intracellular events $\lfloor 2,4\rfloor$. The main argument permitting to propose such a presumption is the fact that the polyribonucleotides having been interacted with the cell penetrate later into it, so these compounds are with no doubt to influence the regulation of intracellular processes. Besides, the dsRNAs are

(C) A. V. KARPCOV, 1998 thought to participate in the IFN induction becaus: they are known to be able to bind some specific proteins - IFN-induced protein kinase and $2^{\prime}, 5^{\prime}-$ oligoadenylatesynthetase - and to change their functional properties [5]. The same presumption is thought to be right for the cases of virus-induced IFN synthesis, the stage of dsRNAs formation able to induce such synthesis having place duriag reproduction cycles of both DNA- and RNA-containing viruses $[2,6]$. The IFN-inducing effect of low molecular weight compounds has been never postulated to be a result of the dsRNAs effect. The mechanism of the IFN induction by tilorone- $\mathrm{HCl}$ and its deritives as well as by some other intercalaling IFN inducers is believed to be due to their dircet irteraction with cell genome [3].

The theory postulating the polynucleotide penc: ration into the cell as a necessary step of the $\operatorname{los}_{1}$ induction has not been accepted by all the authors. An alternative point of view has been proposed concerning the importance of polynuclcotide interactions with the outer cell membranc for the $I F N$ induction. Such an opinion is based, first of all, on the experimental data with a poly (I)-poly (C)-complex 
immobilized on an insoluble carrier. This complex unable to penetrate in to the cell has been, however, detected to induce the IFN synthesis $[7,8]$. Besides, a high quantity of the native and active poly(I) poly (C)-complex has been isolated from cell membrines following cellular IFN synthesis [9].

In the cases of the virus-induced IFN synthesis there is also a pool of experimental data which cannot be interpreted from the point of view based on the cricial role of intracellular dsRNA structures as conductors of the induction signal. Some purified virus envelope proteins hav: been shown to induce the IF. $N$ synthesis $[10,11]$. Simultaneously, the activity of the Newcastle disease virus inducing the IFN synthesis has been detected to be as sensitive to the guanidine, urea, 2-mercaptoethanol, and heat treatment as the virus infectivity. However, both the $U V$-irradiation and the nitrous acid treatment inactivating the viral RNA cause the exponential virus infectivity loss accompanied with the decrease of the INF-inducing activity according to the two-phase kiretics $[12 \mathrm{l}$. Finally, sontetimes there is no correlation between the virus RNA replication and the IFN synthesis.

I am not going to riject the opinion concerning the inportant role of the intracellular dsRNA taking pat in the developing of the signal for the IFN synthesis. However, I think that another process taking place during the primary inducer-cell interactions participates also in this signal development; this process is a specific local deformation of the cell ouler membrane followed by a series of molecular events.

The primary nucleic acid-cell interaction is due to the nucleic acid binding by specific cell receptors. The existence of such presumably protein receptors on the cell surface was earlier postulated [13]. Later nucleic acids receptors were isolated and purified, they were also confirmed to be proteins [14-16]. According to the general receptors function, the next post-binding stage is the active transfer of the receptor-nucleic acid complex into the cell; it should be noted this process to be accompanied by the specifis deformation of the membrane areas where the complex formation and transfer had earlier taken place.

So it should be expected the polynucleotides binding by the cell reccptors to result the analogue or similar result. According to our up-to-date models, the cell membranes have on their surface an outer perimembrane layer as thick as $10-15 \mu \mathrm{m}\{14$, 17) - glyocalyx functioning as a cellular cation exchanger. The glyocalyx structure presenting a specific giant «polyanion» is formied by the carboxylic groups of $\mathrm{N}$-acetylncuraminic acid as well as by ionized phosphate groups residues and protcin amino groups residues [18]. This polyanion participates in a lot of metabolic processes accompanied by the dynamic absorption of cations transferred from and into the cell through the cell pores determining the clectric potential of the plasmatic menbrane surface 118, 19!. The dsRNAs effect on the cell (as well as the iff of synthetic polyionic IFN inducers including portycarboxylates, polysulphates, and polyphosphatcs 1201 taking place without any receptor-mediated binding) is thought to be accompanied by moderate cationic gradients changes followed by cooperative tratisilions in membranes. The next additional binding of caitum leads to the shortening of outer meribranc areas causing (due to mutual cations' repulsion) the formation of the external fluctuating mosaic structure. As a result of new factors action some fluclialing holcs may also appear on the inner membranc surface, sucr a phenomenon having been well described in scientilic literature [21].

At first sight such a process secms to bu ind pendent on the quantity of strands of the îNinducing polynucleotide as well as on the nature of its sugar residue. Such an opinion, however, is in contradiction to the well-known fact concming the IFN-inducing polynucleotides structure; withoul my doubt they are found to contain ribose in their phosphate-sugar chains and to be doublestrandes molecules [4]. I think the specificity of th: IPNinduction by double-stranded polyribonucleonides may be due to their conformational properites and their molecular electrostatic potentials 122$\}$.

Finally, there is also another probable typo. thetical mechanism causing the cell membranc defor mation following its interaction with asRNA nolecules. The double-stranded polyribonucleotides ate known to keep the so-called A-conformation having is base pairs per a helix step as well as the A conformation with 12 base pairs per a helix step. The first conformation is usually found in solutions of physiological $\mathrm{pH}$ and ionic strength values. The increased salt concentrations cause the polyriboulucleotide transition to the $\mathrm{A}^{\prime}$-conformation $[2$ !. Silct: an $A-A^{\prime}$-transition having place in any double-striated polyribonucleotide bound by more than ore receptor. the following decrease of the contour length of double-stranded sequences should causc the specifi cell membrane deformation in the binding aria. My opinion is that the possibility of the mentioned conformational transition may be due to the glyocaly $x$ ionic environment.

An indirect proof permitting to suppose the existence of this last mechanism is the fact 1 t. 11 th: IFN-inducing polyribonucleotides lose almost ailways 
their induction properties after their ribose component modifications; this component is mostly responsible for their conformation. Such a conclusion is a result of data the analysis concerning a lot of doublestranded polyribonucleotides modified in different positions 141 . Taking this analysis into consideration we are now able to understand the inability of DNA molecules as well as of double-stranded deoxyribonucleotides and DNA-RNA-copolymers to cause the $I F N$ induction $[4]$; due to conformational hindrances they are all unable to be IFN inducers as they do not possess any A-conformation at physiological ionic strength values [23].

All the nucleotides being IF $N$ inducers - native dsRNAs as well as synthetic homo- and heteropolymers - meel the case concerning the inducers structure (they are all double-stranded and ribosecontaining); however, different compounds belonging to this group of substances are of different IFN induction ability, the poly (I)-poly(C)-complex possesising the best one [4]. The differences between a lot of syrithetic polynucleotides are explained as a result of different length of their monomeric chains in the reaction mediurn; the chains are able also to interact forming some partially double-stranded sequences simultancously in several points. The complexes obtained are not strictly double-stranded along all their strands; they contain double-stranded regions of differerit lengths interrupted by branching regions, loops, and perhaps also by some one-stranded regions as well as by contacts with some neighbour polynucleotide chains [24]. All these interactions lead to the formation of the reticulate «tertiary structure» of polynucleotide complex molecules. Such a structure is a well-known one for natural dsRNAs. There is an opinion [2.5] the IFN-inducting ability of any polyribonucleotide complex is dependent on its complexity degree influencing the complex-cell interactions followed by the effective/non-effective $\alpha / \beta$-IFN synthesis. The data mentioned above are also applicable to the po'y (I)-poly(C)-complex whose components are different in their ability to form their own secondary structure. 'The poly (I), for example, is able te for.' double-stranded structures at physiological $\mathrm{pH}$ and ioric strength values, this process being dependent on temperature and salt concentration $[4]$; the poly $(\mathrm{C})$ molecules are found to devclop a single-stranded helix [26]. So the interactions of these polynucleotides with their different original configurations leads with the highest probability to the development of the «tertiary struclurc» mentioned above and responsible for the highest ability of the poly(I)-poly (C)-complex to induce the IFN synthesis.

From the point of view of this hypothesis, the most important is the fact that the similar tertiary structure interacting with the cell membrane is to assure the highest density of membrane components contacts with double-stranded polynucleotide regions situated on any local membrane area. It should bc noted such a regularity to be accompanied by increased complexity of polynucleotide structures correlating with their IFN-inducting ability. Such considerations have already experimental support $[25]$.

In the frame of my hypothesis it is also possible to interpret the IFN-inducing mechanism of somic compounds named above and belonging to the clas sical intercalating substances (i. e. aclinomycin b) antrachinone derivatives, trypaflavine, acrydine oran ge) [1] as well as of the best known low moleculat weight IFN-inducing compound - tiloriti- $\mathrm{HCl}$ and its derivatives able also to intercalate 127,281 . Wi: have recently demonstrated the one-stranded $R$ i $V$ molecule to interact with tilorone ones forming spicific IFN-inducing complexes acting both in vito and in vivo $[29,30]$. To explain this phenomenon, we have postulated tilorone to stabilize any partictly complemented areas spontaneously dereloped in solution of any one-stranded RNA preparation. Tiloron. is described to induce the IFN synthesis in wisc onity, but not in the in vitro cultivated cells. This tilorond property can be explained from the data mentioned previously in this review; this conpound appears to interact with small RNA molecules present in the intercellular space in vivo but absent. however, in cell cultures [31]. In the process of extracellular interactions of such molecules with some tilorche's stable double-stranded regions may be also developed; they are able to act as the IFN-inducers.

So I think the IFN-inducing ability is the property of the tilorone-RNA complex but not of this bis molecular compound itself. A simiar situation, i. e. the stabilization of double-stranded regions of cxtrat cellular RNA molecules while their interaction with intercalating ones followed by IFN-inducing cffect of these complexes, is to develop always in every IFN. inducing experiment with intercalating compourds

It would also like to note another plysico. chemical property of tilorone which might tatis been correlated with its higher IFN-inducing abilitv comparing to other intercalating substances. The tiloron: molecule contains lateral chains linked to a flyon nucleus; so the stacking interaction between its chromophore and the DNA bases has been found to bo rather lower comparing to the other eclassicals in $a$. calating compounds. So the lateral intercalating is here more profitable from the energetic point of view, the intercalated tilorone side chains having bcen located in DNA grooves [32]. If this situation takis 
also place with the double-stranded RNA molecules the regional weakening of the negative charge in the sugar-phosphate dsRNA backbone is to cause the rapprochement of the nearest double-stranded regions and the formation of the tertiary reticulate structure discussed above. The similar consequences are to be caused due to tilorone binding to the neighbour single-stranded regions possessing already some double:-stranded arcas.

Finally, the proposed hypothesis concerning the crucial role of the local cell membrane deformation in the process of the signal transfer necessary for the IF $V$ synthesis permits also to interpret the IFNinducing mechanism of viral infections. In fact, the viruses are demonstrated to interact with the cell membrancs in the loci of their contact, this primary interaction influencing significantly the cell metabolism and the cell membrane changes [33]. In particular, the process of the influenza virus penetration into the chicken embryo fibroblasts is shown to be accompanied by the local modifications of hydrophobic plasmatic membrane zones in the points of virus binding [34]. The interactions of the human immunodeficiency virus (HIV) and the Sendai virus with the cell followed by the syncytia formation cause also the decpest changes in cell membrane lipids, their destabilization and re-orientation [35]. The situation observed here possesses a lot of features inkerent to the result of the local membrane deformation. The fact itself that the dsRNA-directed IFN synthesis takes place earlier comparing to the virusinducted one $\{1,2\}$ may be due to the cell membrane detormation differences caused by these IFN-inducing agents.

It remains to mention that the IFN-inducing effect of a such non-specific physical factor as laser irradiation cannot be interpreted in the frame of current hypotheses [36].

To summarize all the data given in this review, l would like to note all the discussed cases of the cell primary interactions with the differcnt types of IFNinducing compounds are accompanied with the sane process, i. e. with the local cell membrane defor mation. I think this process to be a rather general cell reaction developing after the extracellular influence of all the JFN inducers; this process somewhat similar to the simple mechanical effect on the cell possesses, however, some specificity inhibiting the IFN system incuction after any extracellular signal.

It is well known that the development of the extracellular specific signal due to the influence of many biologically active substances interacting with the cell membrane leads to the transfer of this signal mediated by so-called «secondary messengers»
(cAMP, cGMP, $\mathrm{Ca}^{2+}$ ions) [37]. A similar siluation can be also observed following the mechanical influence on the cell membrane $[38-40]$. It seems very probable the principal role in the process of the signal transfer after the membrane deformation to be played exactly by the secondary messengers both in a lot of described cases of gene regulations and in the process of the genes activation coding the $\alpha$ - and $\beta$-IFNs synthesis.

Unfortunately, we have not meanwhile obtained but the fragmentary data permitting to discuss the problem concerning the direct effect of the eclt rilembrane state on the IFN induction. For exaniple. the cell treatment by neuraminidase or hy coli. canavalin $A$ are described to inhibit the IFN svnthesis without any effect on the level of polysi-poly $(\mathrm{C}$; adsorption by cells [41]. It has been also shown the cell treatment by ouabaine, a glycoside substance belonging to the specific inhibitors of $\mathrm{Mg}^{2+}, \mathrm{Na}{ }^{4}, \mathrm{~K}$. and ATP transport through the cell miembrane, stops completely the influenza $B$ virus induced IFN syithesis without changing the virus adsorption. Sucb an effect has been completely eliminated after the preparation's washing off from the cells 1421. Ail thesc data convince the hypothesis concerning the princupa! role of the glyocalyx and perimembranc ions siste $i$ the process of the signal transfer.

It think the next investigations concerning inc cell membrane function in the IFN induction process are to verify the validity of this hypothesis and to determine the nature of the signal switching on the induction of the $\alpha$ - and $\beta$-IFN synthesis.

\section{O. B. Kapnos}

Можливий універсальний механізм передачі снгнаңу пи експресї̈ генів $\alpha / \beta$-інтерферонів. 1. Јокальна ; клітинної мембрани як початковый етап індукцін

Резюме

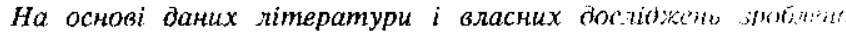

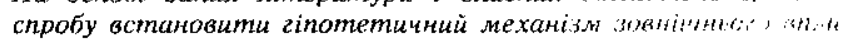

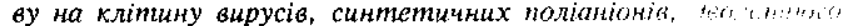

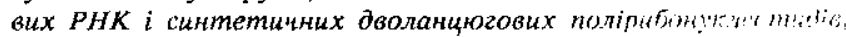

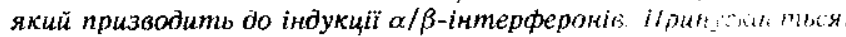

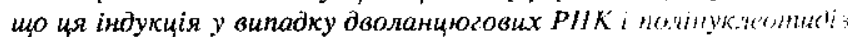

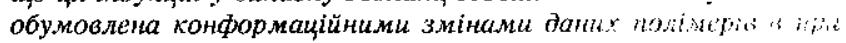

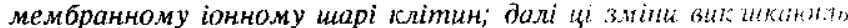
специфічну локальну деформацію клітинної мембрани, "н!; f одним 3 сигналів до індукції $\alpha / \beta$-інтердеронік. $\vee$ ннінік" вірусів подібна деформація мембрани зоійсноения на стаdі

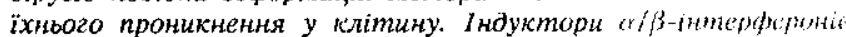
інтеркаляторної природи, скоріи за все, жикликиоль інmир

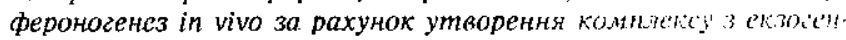

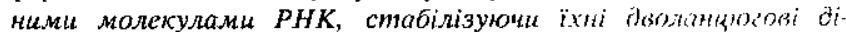
лянки з частковою комплементарністио. 


\section{A. B. Kapnot}

Возможньй унинерсазнныцй механизм передаџи сигжала $\mathbf{k}$ экспрессии геног $\alpha / \beta$-интерферонов. 1. Локальная деформация клеточной мембрраныз как начільный этап индукции

Резкоме

На основании данных питературы и собственных исследований предпринята попытка установить zипотетический механизм внениег; воздейсmєия на клетгу вирусов, синтепінеских попианионов, Dвуспирєиных РНК и синтетических двуспираль-

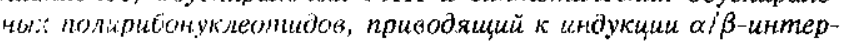
реронов. Предполагантся, ито эна иноукция в слунае двуспиральных РНК и полинуклеотидов обуслоєлена конформацион-

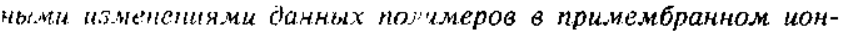

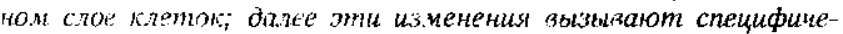
скую локальную деформацию кіспогный мембраны, являющуюсs: одним ӥ сизналов $\kappa$ индукции $\alpha / \beta$-интерреронов. $B$ случае вирусов подор̆ная деформация мембраны происходит на стајии их ппоникиовения о млетку. Индукпори $\alpha / \beta$-интерферонов

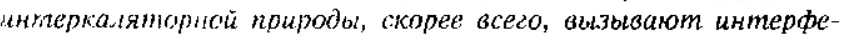
роносене; in vivo вследсmоне образования комплекса с экзогенныли мілекулами РНК, стабитизируя ах деуспиральные участия с настинані комплементарностью.

\section{REIERFNCFS}

1. Ho $M$. Juduction and inducers of interferon // Interferon 1 . General and applied aspecti / Ed. A. Billiau--Amsterdam; New York; Oxford: Elsevier, 1984.-P. 79-124.

2. Marcus $P$. I. Intereron induction by viruses: double-stranded ribonucleic acid as the common proximal inducer molecule // lntereson 3. Mechanisms of production and action / Ed. R. M. Fritdman. --Amsterdam: New York; Oxford: Elsevier, 1984.P. $113-175$.

3. Siringfllto' D. A. Induction of interferon with low molecular weight compounds // Meth. Finzymol,-1981.—78.-T' 262284

4. Turrence P. T., De Clerco $E$. Interferon induction by nucleic acids: strunture-activity relationships // Interferon and their applications / F.ds P. E. Came, W. A. Carter-Berlin: Springer, 1984.-P. 371--3\&3.

5. Vilek $J$. Interferon production and its regulation // Interferon 3. Mechanisms of production and action / Ed. R. M. Friedmatl.--Amsisrdam; New York; Oxford: Hlsevier, 1984.1. $1-10$.

t. Johnston M. D., Burke D. C. Interferon induction ty viruses: molccular requirements // Selective Inhibitors of Viral Func. tions / Ed. W. E. Carter-Cleveland: CRC press, 1973.P. $123-148$.

7. Tayior-Paratimitriou $J$., Kallas $J$. Induction of interferon by «sephas:45e-bound poly(I)-poly(C) // Nature New Bi:1973.-245. N $144 .-\Gamma, 143-144$

8. Pithu P. M., Pitiza J. Interferon induction site: poly $\mathrm{IC}$ on solid substrate cartiers $/ /$ J. Gen. Virol.--1973.-21, N i.P. 31-37.

5. Kohno S., Shirasawo N., Umino Y. et at. Binding of polyriboinosinic-poly ribocyticylic acid with cultured cells // Arch. Virol.-1975.-49, N 2-3.--P. 229-238.

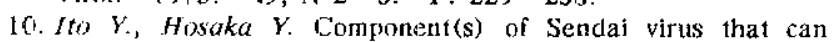
induce interferon in tnouse spleen cells // Infect. Immunol.1983.-39..-

11. Tiensiwacul P., Khoobyarian N. Adenovirus fiber protein priduces synthesis of interferon in mouse spleen and macrophage cultures // Intervirology. - 1983.--20.-P. 52-55.

12. S/u H. I lncerfering and interferon inducing capacity of NDV II. Relationstsip between pyrogenic, interfering, and interferon- inducing activities // Arch. Ges. Virusforsch.-1974.-40, N 3-4.--3. 149.

13. Colby $C$. , Chamberlin $M$. J. The specificity of interferon induction in chick embryo cells by helical RNA // Proc. Nat. Acad. Sci. USA. - 1969.-63, N 1.-P. $160 \ldots 167$.

14. Agrawal S., Goodchild J., Civeira M. P. ct al. Oligodeoxynucleoside phosphoramidates and phosphurothionlates as inhibitors of human immunodeficiency virus // Ibiu.-1988.85, N 19.-P. 7079-7083.

15. Loke S. I., Stein C. A., Zhang X. H. et al. Characterization of oligonucleotide transport into living cells // Ibid.--- $989 . \cdots 86$, N 10.--P. 3474--3478.

16. Yakubov L. A., Deeva E. A., Zarytova V. F. at al Mechanism of oligonucleotide uptake by cells: involvement of specific receptors? // Ibid. -N 17, -P. 6454-6458.

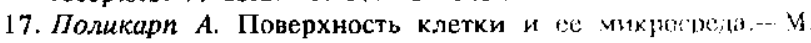
Мир, 1975.-С. 24-25.

18. Голованов М. Д. Анализ строения диойного элек?ричссколо слоя живой клетки // Биофизика.-1995... 40, ํo 2.C. $372-376$.

19. Голованов М. А., Дерягин Б. B. Iloведеяне пазалати ческой мембраны и примембранного слю! (ияьконынко) ! электролите высокой концентрации // бю: жirıрнх. биологии и медицины. - 1992.—№ 8.-C. 210 ‥212

20. Breing $M$. C., Morahan $P$. S. Interferon inducers ponyutions and others // Interferon and interferon inducers / Id. D. A. Stringfellow.-New York: Dekker, 1980.--1'. 230--261.

21. Уильямс $P$. Дж. $П$. Связывание ионин мьтаны) i мембранами и его последствие // Биол. мемо́раны / I Io/ pu.

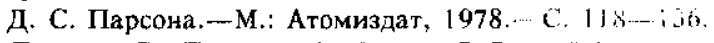

22. Пульман В., Пульман А., Левори Р. Второй бионияня ск: код и молекулярный электростатический пяјенцна." ], жи"

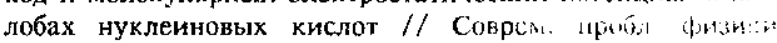

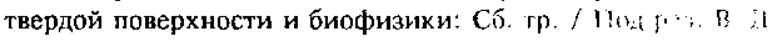
Бахтарьяра.-Киев: Наук. думка, $1982 \ldots$ С. $158 \ldots .07$

23. Arnott $S$. The geometry of nucleic acids $/ /$ f'roge B3inghi... Mol. Biol.-1970.-21.-P. 267-319.

24. Edy V. G., Szekely $M$., Himmelweit $F$, Chain $f$. fr liffect of fragmentation on interferon induction by double-stand: RNA // J. Gen. Virol, -1974,-23, N 2,.. P. $191 \ldots 195$.

25. Вильнер Л. М., Тимковский А. Л., Тихомирияс- (иянден H. С. Биопогическая активность и струкурияе псобенности полинуклеотидных интерфероногены /; Вирусоль-

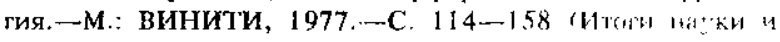
техники, Т. 6).

26. Fasman $G$. D., Lindblow C., Grossman $L$. The titlical conformations of polycytydylic acid: Studies an the forces involved // Biochemistry. - I964.-3, N 8.-P, 1015- I02].

27. Chandra $P$., Zunino $F$., Götz $A$, Bis-DFAF-fluormune: ‘ specific inhibitor of DNA polymerases from RNA Hmont inlise.: // FEBS Le1t. - 1972.-22, N 2.-P. 161- 16.1

28. Chandra P., Zunino F., Gaut V. P. et at Woth ' lition. hydrochloride interaction to DNA and polydevx: ritunude tides // Ibid.--28, N 1.-P. 5-9.

29. Карпов A. B., Жолобак H. $M$. Изучези :ннелиероногенных свойств комплексов дрожжеваз lik - in!ro,it

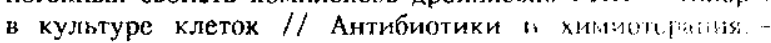
1995.-40, № 5.-C. 20-23.

30. Карпов А. В., Жолобак Н. М. ІІродукіия иятерферовон ! тила в организме под действием молекулярных хоминеке и; дрожжевая РНК - тилорон // Винр. инрусоныния.-1996.-№ 1.-C. $13-16$.

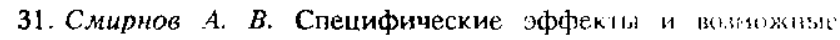

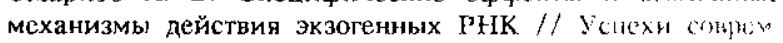
биологии.-1988.-106, № 1.-C. 20--36.

32. Wright R. G. McR., Wakelin L. P. G., Ficlde's A. if al. Ieffects 
of ring substituents and linker chains on the bifunctional intercatation of diacridines into deoxyribonucleic acid // Biochemistry.-1980.-19, N 25.-P, 5825-5836.

33. March $M$., Helenius $A$. Virus entry into aninal cells // Adv. Virus Res.-1989.-36.-P. 107-151.

34. Kірьиаў $Y$. A., I'ораза Л. M. Унлыў пранікнення віруса грылу ұ клетку на ультраструктурную перабудову плазматысных иеморран // Весці АH Беларусі. Сер. біял.-$1992 .-10.5-6,-\mathrm{C} .76-80$.

33. Букринская А. Г., Жданоя В. М. Молекулярные основы nатогенности вируссе--М.: Медицина, 1991.-С. 66--6?

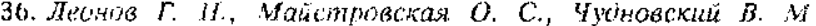
Гелий-ноливое лізерное излучение как индуктор интерферонообразования // Вомр. вирусологии.-1994.№ 13.--C. 119-..121.

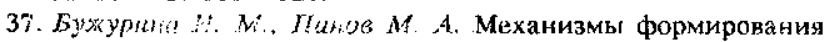

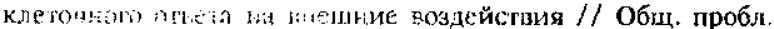
физ.-хим. тиолюни.....: Винити, 1986.-С. 1-258. (Итоти науки и техныки, Т. З)
38. Olsen S.-P., Clapham D. E., Davies P. Li. Hacriodynanic shear stress activates a $\mathrm{K}^{+}$current in vasutar entotheliat ael // Nature.-1988,--331, N 6152.-P. 168--i70.

39. Wang $N$. , Butler J. P., Ingber D. E. Mechandransduction across the cell surface and through the ryoskcleton $/ i$ Science. $-1993 .-260 .-P$. 1124-1127.

40. Watson $P$. A. Direct stimulation of adenylitc cycfaic by

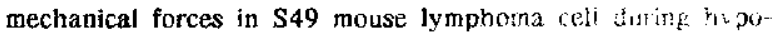
osmotic swelling // J. Biol. Chem..... $990 .-260$, i : $3 . .$. C. $6569-6574$.

41. Pitha P. M., Harper H. D., Pitha I. Dependence of aldertstint induction on cell membrane integrity $/ /$ Virul . . . . $/ 4,4, \cdots-59$, N 1.-P. $40-50$.

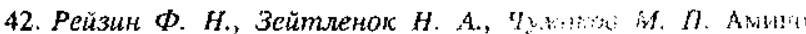

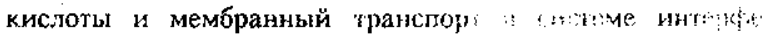

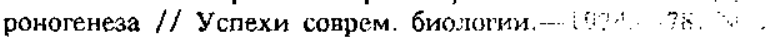
(5), -C. $254-272$.

$R \cdot 42+91$ 